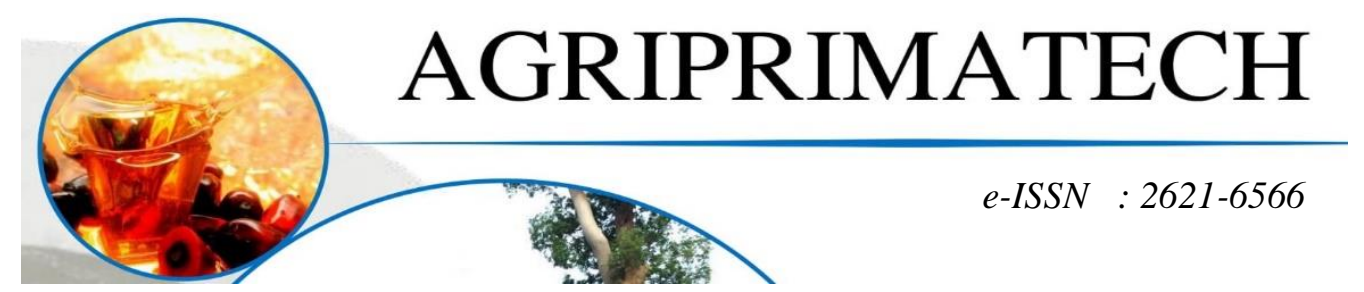

\title{
PENGARUH PENDAPATAN PER BULAN, HARGA, JUMLAH TANGGUNGAN KELUARGA, DAN SELERA TERHADAP KEPUTUSAN MEMBELI MINYAK GORENG CURAH DI PASAR TRADISIONAL
}

\author{
MOHD. NAWI PURBA 1 , SAID RIZAL ${ }^{2}$, YUGO TRIYONO ${ }^{3}$ \\ ${ }^{1}$ Fakultas Ekonomi, Universitas Prima Indonesia \\ 2,3 Fakultas Agro Teknologi Universitas Prima Indonesia \\ Email : mohdnawipurba@unprimdn.ac.id
}

\begin{abstract}
ABSTRAK
Tujuan penelitian ini adalah untuk menganalisis pendapatan per bulan, harga, jumlah tanggungan keluarga, dan selera konsumen minyak goreng curah di lokasi penelitian. Menganalisis pengambilan keputusan konsumen dalam membeli minyak goreng curah, dan untuk mengetahui faktor-faktor yang berpengaruh terhadap keputusan konsumen dalam membeli minyak goreng curah. Pengambilan sampel dilakukan dengan mengggunakan teknik "proportional Random Sampling" dengan sampel sebanyak 100 responden. Metode analisis yang digunakan adalah metode analisis regresi berganda. Pengolahan data dibantu dengan statistical package social science (SPSS) versi 23.

Penelitian ini dilakukan pada bulan Juli 2018. Hasil penelitian dapat disimpulkan bahwa (1) Pendapatan per bulan berpengaruh signifikan dengan keputusan membeli minyak goreng curah di pasar tradisional sei sikambing medan; (2) Harga berpengaruh signifikan dengan keputusan membeli minyak goreng curah di pasar tradisional sei sikambing medan; (3) Jumlah tanggungan keluarga berpengaruh signifikan dengan keputusan membeli minyak goreng curah di pasar sei sikambing medan; (4) Selera tidak berpengaruh signifikan dengan keputusan membeli minyak goreng curah di pasar tradisional sei sikambing medan; (5) Pendapatan per bulan, harga, jumlah tanggungan keluarga, dan selera berpengaruh signifikan dengan keputusan membeli minyak goreng curah di pasar tradisional sei sikambing medan.
\end{abstract}

Kata kunci : Keputusan, Membeli, Minyak Goreng, Pemasaran.

\section{PENDAHULUAN}

Komoditi kelapa sawit merupakan

salah satu andalan komoditi pertanian yang pertumbuhannya sangat cepat dalam perekonomian maupun pembangunan nasional. Kelapa sawit merupakan tumbuhan industri penting penghasil minyak masak, minyak industri maupun turunan lainnya yang berperan penting dalam perekonomian di Indonesia. 
Indonesia merupakan negara agraris penghasil berbagai hasil pertanian baik yang digunakan secara langsung oleh manusia sebagai bahan makanan maupun hasil pertanian yang digunakan seacara tidak langsung sebagai produk industri. Salah satu produk industri yang berbahan baku hasil pertanian adalah minyak goreng. Minyak goreng dari tumbuhan biasanya dihasilkan dari tanaman seperti kelapa, biji - bijian , kacang - kacangan , jagung , kedelai, dan kanola. Aktivitas masyarakat di dapur biasanya berkaitan dengan proses goreng- menggoreng. Konsekuensinya adalah kebutuhan minyak goreng hampir dipastikan cukup besar, yaitu sekitar 3 juta ton per tahun. Artinya konsumsi minyak goreng sekitar $15 \mathrm{~kg}$ kapita per tahun sehingga akan mempengaruhi jumlah permintaan minyak goreng (Sutrisno, 2008). Minyak goreng merupakan salah satu kebutuhan pokok manusia sebagai alat pengolahan bahan-bahan makanan. Minyak goreng berfungsi sebagai media penggorengan sangat penting dan kebutuhannya semakin meningkat. Minyak dapat bersumber dari tanaman, misalnya minyak zaitun, minyak jagung, minyak kelapa, dan minyak biji bunga matahari. Minyak juga dapat bersumber dari hewan, misalnya sarden, ikan paus, (minyak dari sapi) (Ketaren, 1986).

Produk minyak goreng hanya 2 tipe, yaitu minyak goreng kemasan dan minyak goreng curah. Namun konsumen selalu membeli merek dan type yang sama karena dipengaruhi pendapatan, tingkat harga, mutu, selera, dan lain-lain. minyak goreng curah dan minyak goreng kemasan merupakan sama-sama hasil dari proses industri namun berbeda dari kualitas prosesnya. Minyak goreng curah hanya diolah sekali dan mengandung lemak jenuh lebih banyak sehingga kurang sehat untuk kita. Selain itu, pendistribusian minyak goreng curah dari pabrik ke eceran melalui rantai distribusi yang panjang, sehingga dikhawatir aspek higienis minyak curah kurang layak dan tidak memadai untuk konsumen. Meskipun minyak goreng kemasan banyak beredar dipasaran dan Kian gencar melakukan promosi tetapi minat konsumen terhadap minyak goreng curah tergolong tinggi. Padahal dari segi kualitas dan kebersihan, minyak goreng curah masih lebih rendah dari minyak goreng kemasan.

\section{METODE PENELITIAN}

Tempat penelitian ini adalah di Pasar Tradisional Sei Sikambing Medan dan waktu penelitian selama 1 bulan yaitu pada bulan juli 2018. Menurut data BPS (2016) di Kecamatan Medan Helvetia kelurahan Sei Sikambing Cll adalah sejumlah 2.990 Rumah Tangga dengan jumlah penduduk 12.827. Data yang dikumpulkan dalam penelitian ini terdiri dari data primer dan data sekunder. Data primer adalah data yang diperoleh secara langsung dari sumber informasi dengan menggunakan instrument kuesioner dan wawancara. Sedangkan data sekunder diperoleh secara tidak langsung melalui pihak ketiga seperti, BPS Sumatera Utara, internet dan instasi lain terkait.

\section{HASIL DAN PEMBAHASAN}

\section{Pengaruh Variabel Pendapatan Per Bulan, Harga, Jumlah Tanggungan Keluarga, Dan Selera Secara Silmutan terhadap Keputusan Membeli}

Berdasarkan hasil uji $\mathrm{F}$ diperoleh nilai signifikan adalah 0,000 . Dengan demikian variabel yang terdiri dari pendapatan per bulan, harga, jumlah tanggungan keluarga dan selera berpengaruh secara bersama - sama (simultan) terhadap keputusan pembelian minyak goreng curah di pasar tradisional Sei sikambing Medan. 40 
Agriprimatech

Vol. 3 No. 2, April 2020

Berdasarkan analisis regresi berganda pada lampiran di peroleh nilai koefisien determinasi $\mathrm{R}$ Square $=0,957$. Ini ditunjukkan bahwa 95,7\% variasi dari variabel keputusan pembelian dipengaruhi oleh pendapatan per bulan, harga, jumlah tanggungan keluarga dan selera. Sisanya sebesar 5,3\% dipengaruhi oleh variabel lain.

Hasil penelitian ini menunjukkan masih ada variabel lain selain pendapatan per bulan, harga, jumlah tanggugan keluarga dan selera yang mempengaruhi keputusan pembelian tapi tidak dimasukkan dalam model analisis. Berdasarkan model prilaku pembelian konsumen menurut dari psikolog Kurt Lewin yang menyatakan masih ada variabel lain yang berpengaruh terhadap keputusan pembelian seperti faktor ekonomi, sosial, gaya hidup dan faktor pribadi.

\section{Pengaruh variabel pendapatan per bulan secara parsial terhadap keputusan Membeli}

\footnotetext{
Berdasarkan uji t pada Tabel didapatkan koefisien pengaruh variabel pendapatan per bulan terhadap keputusan pembelian minyak goreng curah adalah 25,604 dengan signifikan $0,000<0,05$. Yang artinya pendapatan per bulan berpengaruh secara parsial terhadap keputusan membeli minyak goreng curah di pasar tradisional sei sikambing medan.

Sehingga hasil penelitian ini sependapat dengan teori (Setiadi, 2003) yang menyatakan Pendapatan masyarakat mencerminkan daya beli masyarakat. Tinggi atau rendahnya pendapatan masyrakat akan mempengaruhi kualitas maupun kuantitas permintaan. Pendapatan yang lebih rendah berarti bahwa secara total hanya ada uang yang sedikit untuk dibelanjakan, sehingga masyarakat akan membelanjakan lebih sedikit uang.
}

e-ISSN : 2621-6566

\section{Pengaruh variabel harga secara parsial terhadap keputusan membeli}

Jika permintaan terhadap sebuah barang berkurang ketika pendapatan berkurang, barang tersebut dinamakan barang normal (normal goods).

Dan penelitian ini juga sejalan dengan penelitian yang dilakukan Ismi Mahardini, Nenik Woyanti (2012), yang menyatakan bahwa pendapatan yang diperoleh individu mempunyai pengaruh positif terhadap keputusan untuk membeli.

Berdasarkan uji t pada Tabel didapatkan koefisien pengaruh variabel harga terhadap keputusan pembelian minyak goreng curah adalah 5,863 dengan signifikan $0,000<0,05$. Yang artinya harga berpengaruh secara parsial terhadap keputusan pembelian minyak goreng curah di pasar tradisional sei sikambing medan. Sehingga hasil penelitian ini sependapat dengan teori (Sumarwan, 2004) yang menyatakan Harga adalah jumlah uang yang dibutuhkan untuk memperoleh suatu barang dan pelayanan yang menyertainya.

Konsumen sangat tergantung pada harga sebagai indikator kualitas produk terutama pada waktu harus membuat keputusan pembelian sedangkan informasi yang dimiliki tidak lengkap. Persepsi konsumen terhadap produk sering berubah-ubah seiring dengan perubahan yang terjadi pada harga. Harga merupakan faktor yang sangat berpengaruh dalam keputusan pembelian, apabila harga murah maka konsumen dengan sendirinya tertarik serta diikuti dengan jumlah pembelian yang lebih banyak.

Dan penelitian ini juga sejalan dengan penelitian yang dilakukan Fitrianingrum, dan Tries Edy Wahyono (2013), yang menyatakan bahwa harga menjadi perhatian dalam keputusan pembelian, terutama jika harga terjangkau dan 
Agriprimatech

Vol. 3 No. 2, April 2020

memiliki kualitas yang sama baiknya dengan yang mahal dan mampu mengena di hati konsumen.

Pengaruh variabel jumlah tanggungan keluarga secara parsial terhadap keputusan membeli

Berdasarkan uji $\mathrm{t}$ pada Tabel didapatkan koefisien pengaruh variabel jumlah tanggungan keluaraga terhadap keputusan pembelian minyak goreng curah adalah 2,188 dengan signifikan $0,031>0,05$. Yang artinya jumlah tanggungan keluarga berpengaruh secara parsial terhadap keputusan pembelian minyak goreng curah di pasar tradisional sei sikambing medan.

Sehingga hasil penelitian ini sejalan dengan teori (Sukirno, 2003) yang menyatakan jumlah tanggungan akan mempengaruhi jumlah pembelian terhadap suatu barang. Semakin banyak tanggungan, maka jumlah pembelian akan semakin meningkat. $\mathrm{Hal}$ ini berkaitan dengan usaha pemenuhan akan kecukupan kebutuhan setiap individu yang ada di suatu tempat. Jumlah anggota keluarga sangat menentukan jumlah kebutuhan keluarga. Semakin banyak anggota keluarga berarti semakin banyak pula jumlah kebutuhan keluarga yang harus dipenuhi. Begitu pula sebaliknya, semakin sedikit anggota keluarga berarti semakin sedikit pula kebutuhan yang harus dipenuhi keluarga. Sehingga dalam keluarga yang jumlah anggotanya banyak, akan diikuti oleh banyaknya kebutuhan yang harus dipenuhi.

Dan penelitian ini juga sejalan dengan penelitian yang dilakukan Made Ayu Laksmitha Dewi, dan Ni Putu Martini Dewi (2018), yang menyatakan bahwa Semakin banyak jumlah tanggungan keluarga berarti beban ekonomi yang ditanggung oleh keluarga tersebut semakin berat.
e-ISSN : 2621-6566

\section{Pengaruh variabel selera secara parsial terhadap keputusan membeli.}

Berdasarkan uji t pada Tabel didapatkan koefisien pengaruh variabel selera terhadap keputusan pembelian minyak goreng curah adalah 0,561 dengan signifikan $0,576>0,05$. Yang artinya selera tidak berpengaruh secara parsial terhadap keputusan pembelian minyak goreng curah di pasar tradisional Kota Medan.

Sehingga hasil penelitian ini tidak sependapat dengan teori (Sanusi 2013) yang menyatakan Penentu paling jelas terhadap jumlah pembelian adalah selera. Jika seseorang menyukai suatu barang, maka orang tersebut akan membeli lebih banyak. Para ekonomi biasanya tidak mencoba menjelaskan selera konsumen karena selera didasarkan pada kekuatan-kekuatan historis dan psikologis di luar bidang ilmu ekonomi . menjelaskan Selera merupakan kegiatan seseorang untuk membeli suatu barang atau jasa. Selera konsumen pada umumnya berubah dari waktu ke waktu.

Hal ini dikarenakan hasil yang didapat dilapangan menyatakan bahwa bagi konsumsi rumah tangga yang membeli minyak goreng curah tidak dalam jumlah yang banyak dikarenakan hanya sebagai bahan cadangan kebutuhan pokok apabila minyak goreng kemasan yang juga konsumen gunakan habis saat dibutuhkan. Sementara bagi pedagang membeli dan menggunakan minyak goreng curah dalam jumlah yang banyak hanya untuk kebutuhan pokok dalam berdagang, agar hasil keuntungan yang di dapat lebih besar dibandingkan menggunakan minyak goreng kemasan . Namun penelitian ini sejalan dengan penelitian yang dilakukan Hasbi Munarka, Samsul Bachri, dan Askar (2015), yang menyatakan Bahwa selera tidak berpengaruh terhadap keputusan pembeli. 
Agriprimatech

Vol. 3 No. 2, April 2020

\section{KESIMPULAN}

Berdasarkan hasil investigasi data dan pembahasan dapat di tarik kesimpulan sebagai berikut :

1. Pendapatan per bulan berpengaruh signifikan dengan keputusan membeli minyak goreng curah di pasar tradisional Sei Sikambing Medan.

2. Harga berpengaruh signifikan dengan keputusan membeli minyak goreng curah di pasar tradisional Sei Sikambing Medan.

3.Jumlah tanggungan keluarga berpengaruh signifikan dengan keputusan membeli minyak goreng curah di pasar tradisional Sei Sikambing Medan.

4. Selera tidak berpengaruh signifikan dengan keputusan membeli minyak goreng curah di pasar tradisional Sei Sikambing Medan.

5. Pendapatan per bulan, harga minyak goreng curah, jumlah tanggungan keluarga, dan selera secara bersamasama berpengaruh dengan keputusan membeli minyak goreng curah di pasar tradisional Sei Sikambing Medan.

\section{DAFTAR PUSTAKA}

Amalia, F 2014. Pengertian Konsumen. Diakses Pada Tanggal 19 April 2018.

Antonio, muhammad Syafi'i. 2001. Bank Syariah Dari Teori ke Praktik. Gema Insani Press. Jakarta.

Apriananda Utama, 2013. Faktor-Faktor Yang Mempengaruhi Perilaku Konsumen Membeli Minyak Goreng Curah Studi Kasus : Pasar Sentral di Kecamatan Medan Kota di Kota Medan. Skripsi S1. Fakultas Pertanian Universitas Sumatera Utara. Medan.

$$
\text { e-ISSN :2621-6566 }
$$

Augustine, Y. dan R. Kristaung. 2013. Metodologi Penelitian Bisnis dan Akuntansi. Jakarta: PT Dian Rakyat.

Dewi, Fadila. 2013. Perilaku Konsumen. Palembang: Penerbit Citrabooks Indonesia.

Engel, James et al. 2006. Consumer Behaviour. Mason: Permissions Department, Thomson Business and Economics

Engel, James F, Blackwell, Roger D, and Mimiard, Paul W. 1995. Perilaku Konsumen. Terjemahan : Budiyanto. Binarupa A ksara. Jakarta

Farah Zakia, Zakiah, Safrida. 2017. Faktor-Faktor Yang Mempengaruhi Perilaku Konsumen Dalam Pembelian Minyak Goreng Curah Dan Minyak Goreng Kemasan Studi Kasus Pasar Peunayong Kota Banda Aceh. Jurnal IImiah Mahasiswa Unsyiah . vol 2, no 1.

Hestanto, 2017. Pengertian Pendapatan. http://www.hestanto.web.id/pengert ian-pendapatan/ Diakses Pada 19 April 2018.

Ikatan Akuntan Indonesia (IAI).2009. Standar Akuntansi Keuangan revisi 2009. Salemba Empat. Jakarta. Ketaren, S. 1986. Pengantar Teknologi Minyak Dan Lemak Pangan. Cetakan Pertama. Jakarta : UI-Press. Kotler, Philip. 2001. Manajemen Pemasaran: Analisis, Perencanaan, Implementasi dan Kontrol. Jakarta: PT. Prehallindo

Kotler, Philip dan Amstrong, Gary. 2008. Prinsip-Prinsip Pemasaran. Jilid 1.Edisis ke 12. Ahli Bahasa Bob Sabran. Jakarta : Erlangga. 
Agriprimatech

Vol. 3 No. 2, April 2020

e-ISSN : 2621-6566

Mowen, J.C. dan Minor, Michael. 2006. Perilaku Konsumen. Jilid 2 Edisi Kelima. (Diterjemahkan oleh : Lina Salim). Erlangga. Jakarta.

Philip Kotler, 2005. Manajemen Pemasaran Jilid I dan II. PT, Indeks Jakarta.

Riduwan. 2010. Skala Pengukuran Variabel-variabel Penelitian. Bandung: Alfabeta.

Ristiyanti Prasetijo, (2004), Perilaku Konsumen, Yogyakarta, Penerbit Andi.

Singgih Santoso. 2002. SPSS Versi 11.5 Cetakan Kedua Jakarta: Gramedia

Sanusi, Bachrowi. 2003. Ekonomi Mikro : Suatu Pengantar. Universitas Trisakti. Jakarta

Setiadi, N.J. 2003. Perilaku Konsumen dan Implikasi untuk Strategi dan Penelitian Pemasaran. Kencana. Jakarta

Simamora, B. 2006. Panduan Riset Perilaku Konsumen. PT. Gramedia Pustaka. Jakarta. 